\title{
The Effectiveness of Using Hyacinth Plant As Phytoremediation Agent On Paper Industry Liquid Waste
}

\author{
Ika Kartika Febriani $^{1}$ and Hadiyanto ${ }^{1,2}$ \\ ${ }^{1}$ Master Program of Environmental Science, School of Postgraduate Student Diponegoro University \\ ${ }^{2}$ Chemical Engineering Dept, Faculty of Engineering, Diponegoro University
}

\begin{abstract}
Increasing number of industry in Indonesia lead to produce large amount of waste. If the waste is not treated by phytoremediation, it will pollute the environment. One method to overcome this problem is phytoremediation process. Phytoremediation is the use of plant to reduce pollutants in both organic and inorganic compounds as well as to remove the contaminants. This study aims to evaluate the effectiveness of water hyacinth plant in absorbing paper industry liquid waste. Observations were made with phytoremediation of time $0,7,14$, and 21 days with 2 treatment ie treatment covered by plastic and treatment not covered by plastic and by 4 concentration dilution ie $100 \%$ liquid waste, $75 \%$ liquid waste, $50 \%$, and $25 \%$. The result should that after 21 days of water hyacinth can reduce the COD level with the highest efficiency level of $1.63 \%$, then BOD of $4.29 \%$.
\end{abstract}

Keywords: liquid waste; paper industry; phytoremediation; water hyacinth

\section{Introduction}

Growth of technological progress in Indonesia has been growing, especially technological progress in the field of Industry. Rapid and growing industrial growth produces more and more waste. Waste generated by industrial activities one of them is liquid waste. Liquid waste when discharged into the waters and not treated in advance can cause direct or indirect impacts on microorganisms, macroorganisms, and even in humans. Therefore it is necessary to process liquid waste to be safe for all living things.

One of the simplest and most effective and efficient waste treatment techniques is phytoremediation. Phytoremediation itself utilizes the ability of plants to absorb and eliminate water contamination. In the process, the plant is used as a waste treatment agent, to reduce, transfer, and stabilize contaminants in water [1]. This technique can be done by anyone and anywhere because it is quite easy and economical compared to other techniques [2].

Water hyacinth is one plant that is resistant to all kinds of conditions. Therefore in this study will use water hyacinth plant as phytoremediation agent. Water hyacinth is a water plant that is considered as a weed because it destroys the ecosystem and its growth is very fast. Water hyacinth can grow and develop in polluted waters so that water hyacinth can be utilized to overcome the pollution caused by industry activity [3]. Water hyacinth itself has the potential to absorb heavy metals because this plant has a high tolerance properties so it can grow well on waste and can reduce BOD and COD in wastewater [4].

This study aims to test the effectiveness of water hyacinth plants in the process of absorbing pollution caused by paper industry activities. The absorption process performed by water hyacinth is affected by temperature, ph, and detention time [5]. In the Lutfiana [6] study, 3 treatments were done, treatment A (water hyacinth), B (kangkung) and C (apu wood) and the result of the three plants were able to decrease the organic matter content in the experimental media. Water hyacinth, watercress, apu wood can absorb the organic ingredients successively until the remaining $195 \pm 48.61$ $\mathrm{mg} / 1,388.50 \pm 90.22 \mathrm{mg} / 1$ and $400 \pm 98.89 \mathrm{mg} / 1$. Treatment A by using water hyacinth (Eichhornia sp.) Gives satisfactory results as a phytoremediation agent. Hyacinth has a supportive body structure to affect the ability to absorb organic materials and other substances in water.

\section{Research Methods}

The research was conducted in February 2018 until April 2018. Located in Rawamerta Village, Kabupaten Karawang, West Java. Sample of waste obtained from one of industrial pulp and paper in karawang. The materials used in the research are water hyacinth, ground

\footnotetext{
Corresponding author: ikakartikafebriani@gmail.com
} 
water, waste paper industry waste samples. The equipment used in the research is spectrophotometer, digital scales, $\mathrm{pH}$ meters heating block, BOD inductor, DO meters, tub volume 20L. The experiment was conducted using Group Random Design (RAK), 4x2 factorial pattern with 3 replications. The first factor is the condition of the closed tub and without closing then the second factor is the length of time to live water hyacinth in research basin. With diluted waste treatment with concentrations of $25 \%, 50 \%, 75 \%$ and $100 \%$ (without dilution). Each concentration was then analyzed. Industrial waste dilution is carried out with the addition of ground water, the volume of the tub used is 20L. In each bucket were added $15 \mathrm{~L}$ industrial waste, $12.5 \mathrm{~L}$ industrial waste, $10 \mathrm{~L}$ industrial waste, $7.5 \mathrm{~L}$ industrial waste. Each treatment planted water hyacinth with weight 300 gram. The growth of water hyacinth is observed every 7 days for 21 days.

Plant acclimatization The samples of water hyacinth plants are acclimatized to allow the plants to adapt to their environment. Acclimatization is done for 7 days with clean water on a tub with volume 20L. After acclimatization for 7 days then selected the samples of water hyacinth plant to be used as phytoremediator. The selected plant samples are fresh green leaf and have relatively equal size for each type of aquatic plants. The water hyacinth used plants have specifications with the criteria: the number of leaves 3-6 pieces, the leaves are still fresh and not yellowing, plant height $10-15 \mathrm{~cm}$. The selected plant samples were each incorporated into a research reactor containing the water of the liquid waste solution in accordance with the experimental design. Phytoremediation performed is phytoremediation with a batch flow, in which water is stationary and immobile. Measurements of COD, BOD and DO in wastewater were carried out by sampling on days $0,7,14$, and 21 . Sampling was performed by taking $100 \mathrm{ml}$ of waste water per parameter from each treatment.

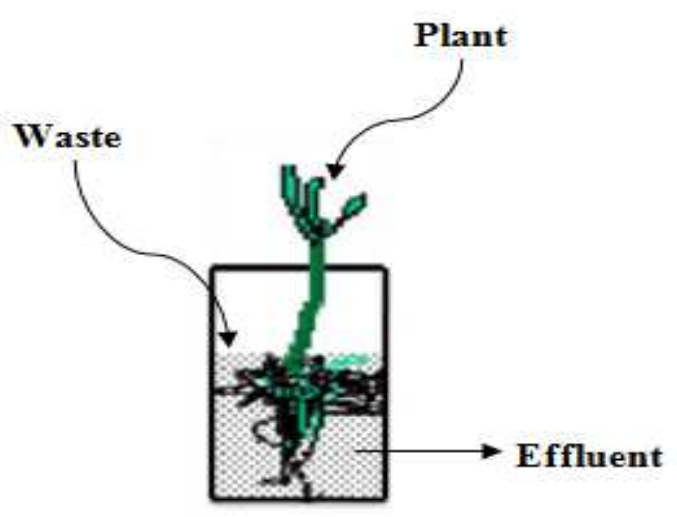

Fig 1. Scheme of Phytoremediation Mechanism

\section{Results and Discussion}

3.1The Efficiency of Remediation Calculate byUsing Water Hyacinth

$$
E f=\frac{C o}{C s} \times 100 \%
$$

Ef : processing efficiency using phytoremediation with contact time $\mathrm{t}$

Co : initial waste parameter concentration

Cs : concentration parameters after processing

This study aims to determine the results of absorption made by water hyacinth plant caused by paper industry liquid waste. The hyacinth plant used is derived from waters filled with water hyacinth. The selected hyacinth plant is a plant that has the same size and has 3-6 leaves, the leaves are still fresh and not yellowing. Plants hyacinth many scattered in almost all waters, because the nature of water hyacinth that is easy to adapt to the environment makes this plant has a considerable population. To overcome the problem of water hyacinth that many population hence required the utilization of water hyacinth. In this study water hyacinth is used as phytoremediation agent. Phytoremediation is the utilization of certain plants to remove pollutants from soil or waters contaminated with certain pollutants.

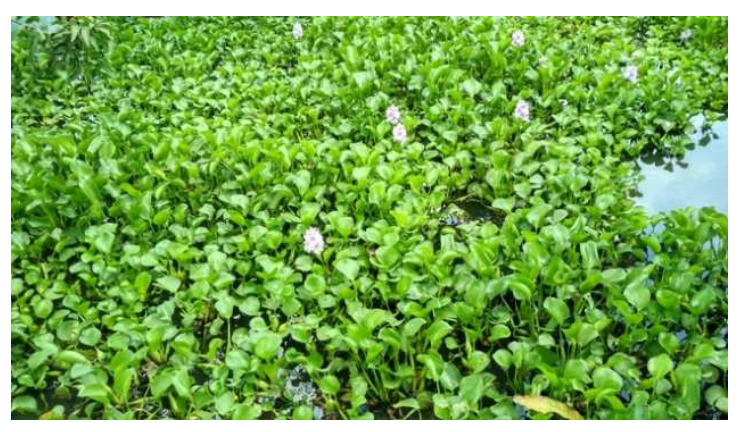

Fig 2. Water hyacinth plant

The parameters observed were COD, BOD and DO. These three parameters have different effects on the waters. If the parameters mentioned earlier entered the waters exceeded the standard of Regulation No. 82 of 2001 [7] it will disrupt life in the water and will damage the environment. The quality standard used herein shall be a class 2 quality standard whose designation may be used for recreational water facilities, freshwater fish farming, livestock, water to irrigate crops, and / or other designations that require the same water quality as those uses. Therefore, before the waste water into the waters need to be done first in order to dispose of waste water is safe for the environment.

This study also aims to determine the effectiveness of hyacinth plants in absorbing pollution caused by paper industry liquid waste. In this research, there are 2 treatments on the experimental bath, ie closed treatment and open treatment. Given 2 treatments in order to see which treatment is more effective to give optimal results when water hyacinth is phytoremediated. 
Can be seen in the picture below treatment on a tub experiment.

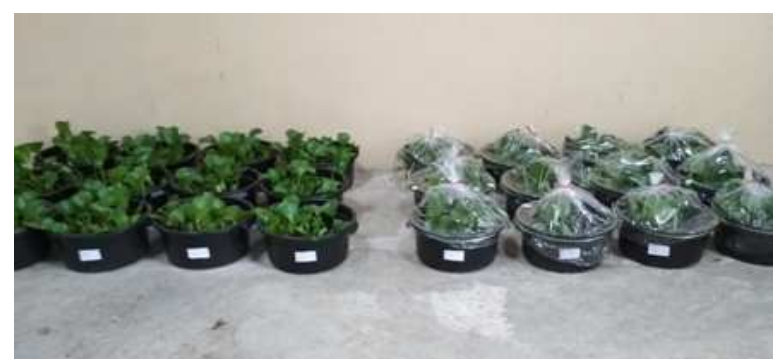

Fig 3. Bath phytoremediation experiment

From the results of observations for 21 days obtained results for each treatment. There are differences in outcomes at each treatment. Observations were observed in the form of COD, BOD, and DO.

\subsection{COD}

Chemical Oxigen Demand (COD) is the total amount of oxygen needed to oxidize chemically organic materials, both biodegradable and biologically degradable to $\mathrm{CO}_{2}$ and $\mathrm{H}_{2} \mathrm{O}$ [8]. The existence of organic materials can come from nature or from household and industrial activities. Waters with high COD values are not good for fishing and farming activities. The figure below shows the reduction of COD in the paper industry liquid waste by using phytoremediation technique in which water hyacinth is the agent.

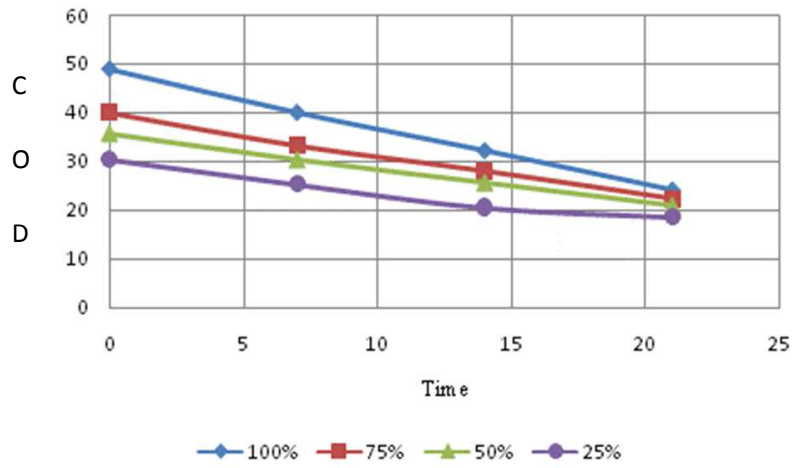

Fig 4. COD Observation in Open Box System

Table 1. Table of COD decrease by Water Hyacinth

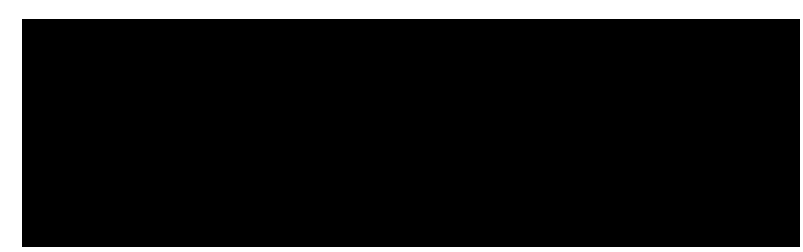

Decrease in COD is caused by microorganisms found in the root of water hyacinth. Phytoremediation process is a process that has an important role in the absorption of organic pollutant content. As long as the root of the hyacinth plant continues to grow then during that time the plant can absorb contamination. The root of water hyacinth is overgrown with many microorganisms. This is what affects the effectiveness of water hyacinth in lowering the COD value of the waste, the more microorganisms that grow, the more effective is the decrease of its COD as the number of microorganisms is increasing and the microorganism is able to adapt well to the environment [9].

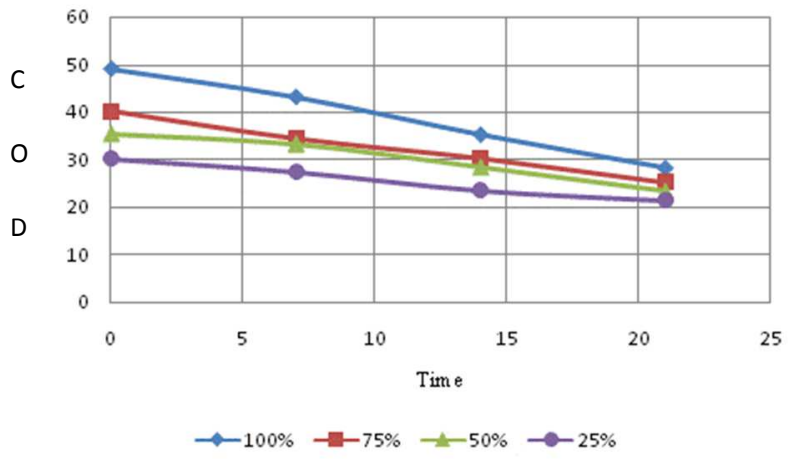

Fig 5. COD Observation in Closed Box System

From the description above graph can be seen that the treatment of phytoremediation using water hyacinth plant can reduce the COD content of paper industry liquid waste. Waste decreases every week. Different treatments also affect the effectiveness of COD levels decreased by water hyacinth. The effectiveness value of COD decrease during phytoremediation waste treatment using hyacinth plant can be seen in the following table.

Table 2. Table of COD decrease by Water Hyacinth

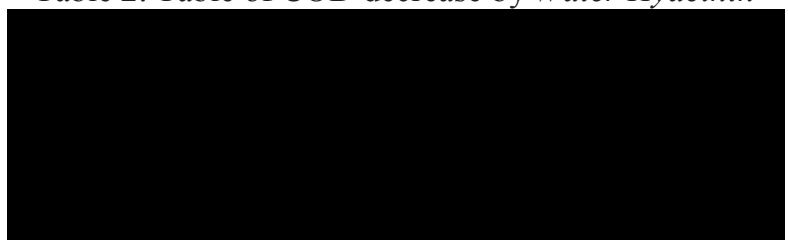

From the table above can be seen that the media planted water hyacinth can reduce the COD in the liquid waste of 0.033 on the open conditions ago amounted to 0.026 on closed conditions.

\subsection{BOD}

Biologycal Oxigen Demand (BOD) is the amount of oxygen needed by microorganisms to decompose its decomposely organic material. Organic materials that do not decompose are generally derived from agricultural, mining and industrial waste. So the more organic matter in the water, the bigger the BOD while the DO (Dissolved Oxygen) will be lower. DO is the dissolved oxygen contained in water, derived from the air and the result of photosynthetic process of aquatic plants. Oxygen is required by all creatures that live in water such as fish, shrimp, shellfish and other animals including microorganisms such as bacteria. The table below shows the BOD dilution of the paper industry's liquid waste by using phytoremediation techniques in which water hyacinth is the agent. 


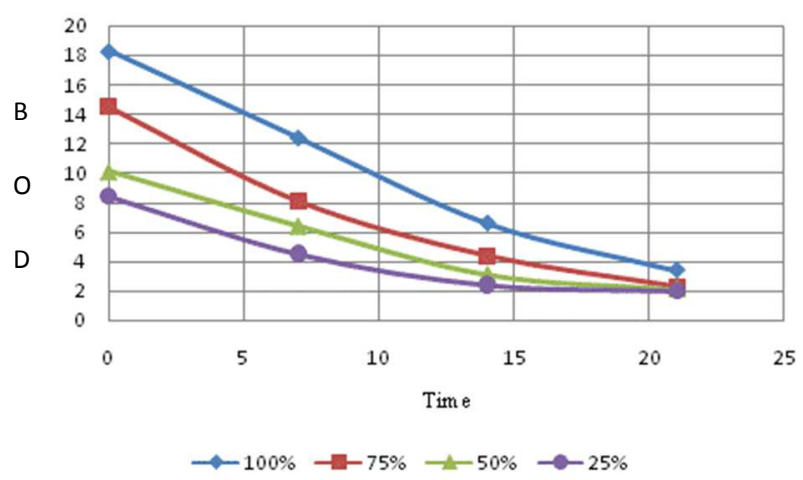

Fig 6. BOD Observation in Open Box System

Table 3. Table of BOD decrease by Water Hyacinth

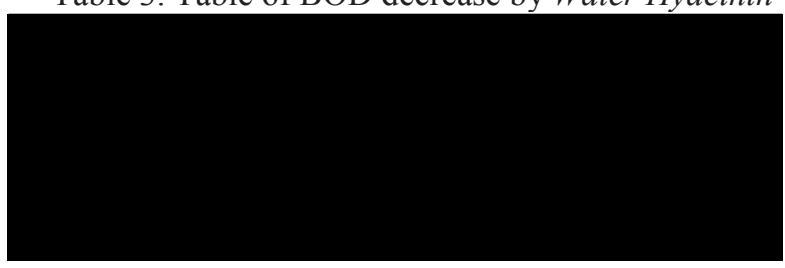

During the process of liquid waste using water hyacinth as phytoremediation agent, the average of BOD value at various concentration of liquid waste has decreased. This is because the amount of oxygen required by microorganisms to decompose organic matter biologically begins to decrease with increasing oxygen dissolved in water due to photosynthetic activity [10].

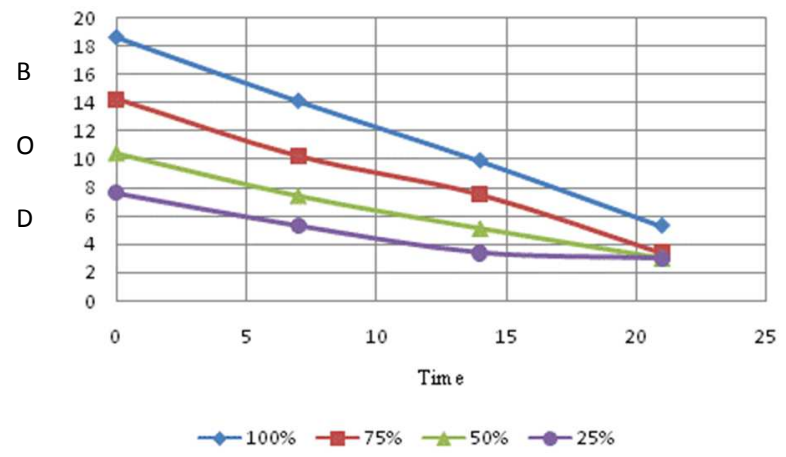

Fig 7. BOD Observation in Closed Box System

Table 4. Table of BOD decrease by Water Hyacinth

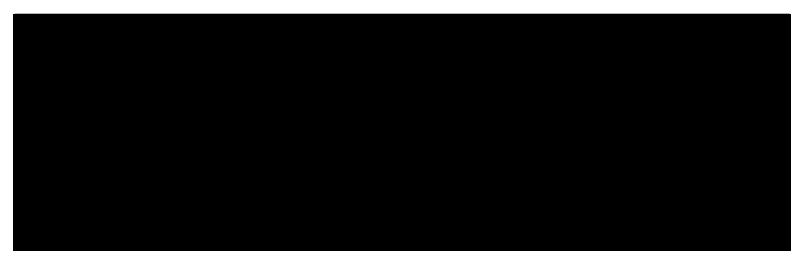

From the description above graph can be seen that phytoremediation treatment using hyacinth plant can decrease BOD content of paper industry liquid waste. Waste decreases every week and from the table above can be seen that the media planted water hyacinth can reduce the BOD in the liquid waste of 0.081 on the open conditions ago amounted to 0.059 on closed conditions.

\subsection{DO}

Dissolved oxygen (DO) or often also called oxygen demand (oxygen demand) is one of the important parameters in water quality analysis. The value of DO usually measured in the form of this concentration indicates the amount of oxygen $\left(\mathrm{O}_{2}\right)$ available in a body of water. The greater the DO value on water, indicating the water is of good quality. Conversely, if the $\mathrm{DO}$ value is low, it can be seen that the water has been contaminated. Measurements DO also aims to see the extent to which the body of water is able to accommodate water biota such as fish and microorganisms. In addition, the ability to clean water pollution is also determined by the amount of oxygen in the water. The graph below shows the availability of DO in the paper industry liquid waste by using phytoremediation techniques in which water hyacinth is the agent.

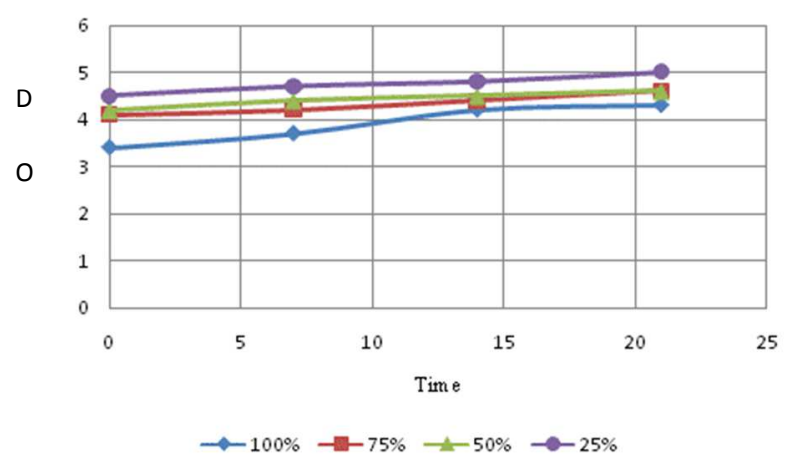

Fig 8. DO Observation in Open Box System

Table 5. Table of DO decrease by Water Hyacinth

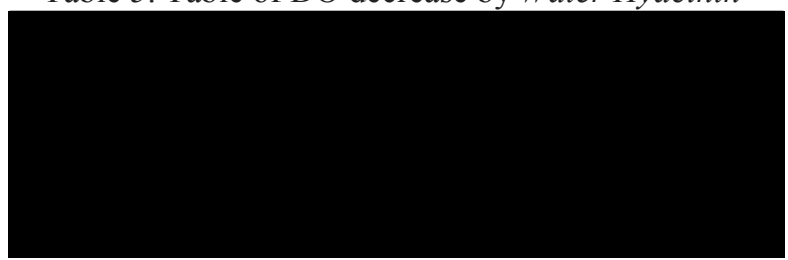

One of the parameters affecting water quality is dissolved oxygen or Dissolved Oxygen (DO). The oxygen available in water is one of the determinants of the aquatic life (Mubarak et al, 2010 in Prahutama, 2013). Water quality can be seen from the measurement of dissolved oxygen level or Dissolved Oxygen (DO), if the DO content is high then the water quality is better [11].

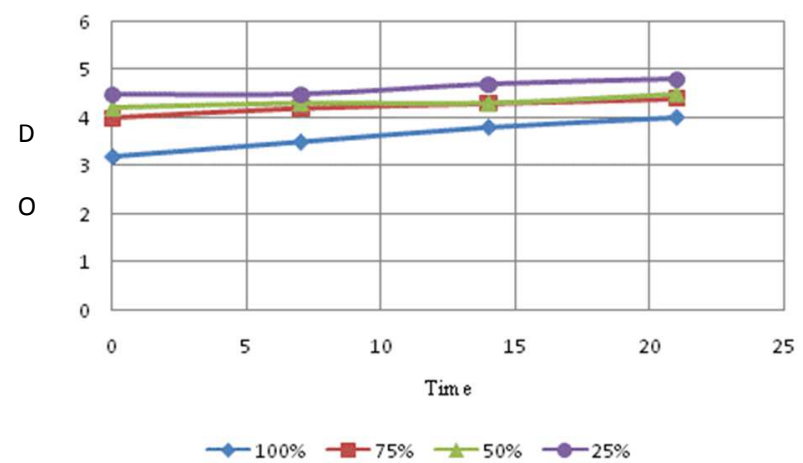

Fig 9. DO Observation in Closed Box System 
Table 6. Table of DO decrease by Water Hyacinth

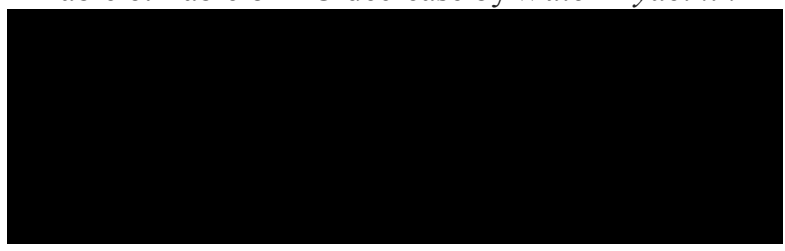

From the description above graph can be seen that phytoremediation treatment using hyacinth plant can raise DO waste paper industry waste. Waste increases every week. Different treatments also affect the effectiveness of decreased levels of DO by water hyacinth. The effectiveness of DO reduction during phytoremediation waste treatment using hyacinth plant can be seen in table and from the table above can be seen that the media planted water hyacinth can raise the DO on liquid waste of 0.011 on the open conditions ago amounted to 0.010 on closed conditions.

\section{Conclution}

Based on the results of the research, it can be concluded that, the closure of the tub of research gives different results from research basins that are not closed. The 21-day study provided maximum results for the reduction of COD and $\mathrm{BOD}$ as well as raising the value of DO liquid waste paper. From the results of this study can be concluded that the water hyacinth plants can reduce the content of COD and BOD and can increase the value of DO in the waste paper industry is quite a maximum for 21 days.

\section{References}

1. Ojoawo, Samson O., Udayakumar, Gaddale., Naik, Pushparaj. Phytoremediation of Phosphorus and nitrogen with Canna $x$ generalis Reeds in Domestic Wastewater through NMAMIT Constructed Wetland. Science Direct, Aquatic Procedia 349 356. (2015)

2. Puspanti, Antum. Kajian Fitoremediasi Sebagai Salah Satu Pendukung Kegiatan Pengelolaan Lahan Paska Penambangan Batubara. Balai Penelitian Teknologi Konservasi Sumber Daya Alam. (2013)
3. Kris, S. Dan Wariningsih. Pemanfaaatan Eceng Gondok Untuk Membersihkan Kualitas Air Sungai Gadjahwong Yogyakarta. Jurnal Teknologi Technoscientia Vol. 4 No 1. (2011)

4. Zayed. Phytoaccu-Mulation Of Trace Elements By Wetland Plants: I. Duckweed. Journal Environmental Quality; 27: 715-721. (1998)

5. Handoko. Penurunan Konsentrasi Fenol Dengan Memanfaatkan Enceng Gondok (Eichornia crassipes) Pada Limbah Cair PT. Siak Raya Timber. Pekanbaru: Fakultas Perikanan Universitas Riau. (2002)

6. Indah, Lutfiana Sari. Hendrarto, Boedi. Soedarsono, Prijadi. Kemampuan Eceng Gondok (Eichhornia Sp.), Kangkung Air (Ipomea Sp.), Dan Kayu Apu (Pistia Sp.) Dalam Menurunkan Bahan Organik Limbah Industri Tahu (Skala Laboratorium). Diponegoro Journal Of Maquares, V. (2014)

7. Peraturan Pemerintah Nomor 82 Tahun 2001 tentang Pengelolaan Kualitas Air dan Pengendalian Pencemaran Air.

8. Boyd. Water Quality in Warmwater Fish Ponds. Alabama Agricultural Experiment Station. United States. 359 h. (1998)

9. Setiadi, Tjandra., Pertiwi, Fransisca I., Widyarsa, Irma I., Pengolahan Limbah Cair Industri Tekstil yang Mengandung Zat Warna Azo Reaktif dengan Proses Gabungan Anaerob dan Aerob. Laboratorium Mikrobiologi dan Teknologi Bioproses. Jurusan Teknik Kimia Institut Teknologi Bandung. Bandung. (1999)

10. Axler, R. Hagley, C. Host, G. Merrick, G. Meyer, N. Munson, B. Richards, C. Ruzycki, E. Svenden, C. Yoon, J. Water on The Web II. (2004)

11. Simanjutak, M. Oksigen Terlarut dan Apparent Oxygen Utilization di Perairan Teluk Klabat Pulau Bangka. Jurnal Ilmu Kelautan Vol 12 (2):59-66. (2007) 